\title{
Genetic Screening for Familial Gastric Cancer
}

\author{
Carla Oliveira', Gianpaolo Suriano', Paulo Ferreira', Paulo Canedo', Pardeep Kaurah', \\ Rita Mateus', Ana Ferreira', António C. Ferreira' ', Maria José Oliveira' , Céu Figueiredo',3, \\ Fátima Carneiro, ${ }^{1,3}$, Gisela Keller, David Huntsman², José Carlos Machado ${ }^{1,3}$, Raquel Seruca ${ }^{1,3}$
}

IInstituto de Patologia e Imunologia Molecular da Universidade do Porto (IPATIMUP), Porto, Portugal; 2 Hereditary Cancer Program, British Columbia Cancer Agency, Vancouver BC, Canada; 3Faculdade de Medicina da Universidade do Porto, Porto, Portugal; 4 Institute of Pathology, Klinikum rechts der Isar, Technische Universität München, Germany

Key words: gastric cancer, familial gastric cancer, E-cadherin, CDHI, HDGC, hereditary diffuse gastric cancer, inheritance, germline mutation, missense mutation, Helicobacter pylori, low penetrance genes, ILI, TNF $\alpha$, early onset, genetic counselling, functional analysis

Corresponding author: Raquel Seruca, IPATIMUP, Rua Dr Roberto Frias s/n, 4200-465 Porto, Portugal. Phone +351225570774 , fax+351 22 5570799, e-mail: rseruca@ipatimup.pt

Submitted: 14 May 2004

Accepted: 16 May 2004

\begin{abstract}
Approximately 10\% of gastric cancer cases show familial clustering but only 1-3\% of gastric carcinomas arise as a result of inherited gastric cancer predisposition syndromes. Direct proof that Hereditary Gastric Cancer is a genetic disease with a germline gene defect has come from the demonstration of co-segregation of germline E-cadherin (CDH1) mutations with early onset diffuse gastric cancer in families with an autosomal dominant pattern of inheritance (HDGC). E-cadherin is a transmembrane calcium-dependent cell-adhesion molecule involved in cell-junction formation and the maintenance of epithelial integrity. In this review, we describe the frequency and type of $\mathrm{CDH} 1$ mutations in sporadic and familial gastric cancer. Further we demonstrate the functional significance of some $\mathrm{CDH} 1$ germline missense mutations found in HDGC. We also discuss the CDH1 polymorphisms that have been associated to gastric cancer. We report other types of malignancies associated to HDGC, besides diffuse gastric cancer. Moreover, we review the data available on putative alternative candidate genes screened in familial gastric cancer. Finally, we briefly discuss the role of low-penetrance genes and Helicobacter pylori in gastric cancer. This knowledge is a fundamental step towards accurate genetic counselling, in which a highly specialised pre-symptomatic therapeutic intervention should be offered.
\end{abstract}

\section{Introduction}

Gastric cancer is one of the most common gastrointestinal malignancies world-wide, although in recent decades a decline has been observed in its incidence and associated mortality [1,2]. Gastric cancer is highly heterogeneous morphologically, but there are two main histotypes of gastric carcinoma: the glandular (intestinal) type and the isolated-cell type (diffuse). A proportion of cases displays a mixed phenotype harbouring in a single tumour of two histological components (glandular and diffuse) $[3,4]$.

Although the incidence of gastric cancer in older patients is decreasing, the incidence of gastric cancer in younger patients and cases with familial clustering remains quite stable. This suggests that a genetic predisposition may play an important role in the pathogenesis of some forms of gastric cancer [5]. About $10 \%$ of cases of gastric cancer show familial clustering $[2,6]$ but only $1-3 \%$ of gastric carcinomas 
Table 1. Summary of the germline $\mathrm{CDH} 1$ mutation screening studies in families with gastric cancer

\begin{tabular}{|c|c|c|c|c|c|c|c|c|c|}
\hline Study & $\begin{array}{c}\text { Total } \\
\text { of } \\
\text { families }\end{array}$ & $\begin{array}{l}\text { HDGC } \\
\text { families }\end{array}$ & $\begin{array}{l}\text { FDGC } \\
\text { families }\end{array}$ & $\begin{array}{c}\text { FIGC } \\
\text { families }\end{array}$ & $\begin{array}{c}\text { FGC } \\
\text { families }\end{array}$ & $\begin{array}{c}\mathrm{CDH1} \\
\text { truncating } \\
\text { mutations }\end{array}$ & $\begin{array}{c}\mathrm{CDH} 1 \\
\text { missense } \\
\text { mutations }\end{array}$ & $\begin{array}{l}\% \mathrm{CDH} 1 \\
\text { mutations } \\
\text { in HDGC }\end{array}$ & $\begin{array}{l}\% \mathrm{CDH} 1 \\
\text { mutations } \\
\text { in FDGC }\end{array}$ \\
\hline Guilford et al, 1998 [9] & 3 & 3 & 0 & 0 & 0 & 3 & 0 & $100 \%$ & $0 \%$ \\
\hline Gayther et al, 1998 [10] & 18 & 10 & 0 & 8 & 0 & 3 & 0 & $30.0 \%$ & $0 \%$ \\
\hline Richards et al, 1998 [1 1] & 8 & 8 & 0 & 0 & 0 & 2 & 0 & $25.0 \%$ & $0 \%$ \\
\hline Guilford et al, 1999 [12] & 6 & 4 & $2^{* *}$ & 0 & 0 & $6^{* *}$ & 0 & $100 \%$ & $100 \%$ \\
\hline Shinmura et al, 1999 [13] & 13 & 3 & 0 & 10 & 0 & 0 & 1 & $33.3 \%$ & $0 \%$ \\
\hline Yoon et al, 1999 [85] & 5 & 5 & 0 & 0 & 0 & 0 & 2 & $40 \%$ & $0 \%$ \\
\hline lida et al, 1999 [86] & 14 & 0 & 6 & 6 & 2 & 0 & 0 & $0 \%$ & $0 \%$ \\
\hline Keller et al, 1999 [44] & 7 & 2 & 5 & 0 & 0 & 1 & 0 & $50.0 \%$ & $0 \%$ \\
\hline Avizienyłe et al, 2001 [87] & 11 & 5 & 4 & 1 & 1 & 0 & 0 & $0 \%$ & $0 \%$ \\
\hline Dussaulx-Garin et al, 2001 [88] & 1 & 1 & 0 & 0 & 0 & 1 & 0 & $100 \%$ & $0 \%$ \\
\hline Humar et al, 2002 [89] & 10 & 7 & $3^{*}$ & 0 & 0 & $5^{*}$ & 0 & $57.1 \%$ & $33.3 \%$ \\
\hline Oliveira et al, 2002 [32] & 39 & 11 & 24 & 4 & 0 & 3 & 1 & $36.4 \%$ & $0 \%$ \\
\hline Yabuta et al, 2002 [26] & 17 & 2 & 3 & 0 & 12 & 0 & 1 & $50.0 \%$ & $0 \%$ \\
\hline Wang et al, 2003 [27] & 78 & 0 & $2^{* *}$ & 0 & 76 & 0 & $2^{* *}$ & $0 \%$ & $100 \%$ \\
\hline Oliveira et al, 2004 [28] & 1 & 1 & 0 & 0 & 0 & 1 & 0 & $100 \%$ & $0 \%$ \\
\hline Jonsson et al, 2002 [25] & 3 & 3 & 0 & 0 & 0 & 1 & 0 & $33.3 \%$ & $0 \%$ \\
\hline Oliveira et al, in press [30] & 32 & 9 & 10 & 3 & 10 & 0 & 1 & $11.1 \%$ & $0 \%$ \\
\hline Keller et al, 2004 [29] & $28^{* * *}$ & 2 & 21 & 5 & 0 & 0 & $1^{*}$ & $0 \%$ & $4.8 \%$ \\
\hline Brooks-Wilson et al, in press [31] & 34 & 26 & $7^{*}$ & 1 & 0 & 10 & $3^{*}$ & $46.2 \%$ & $14.3 \%$ \\
\hline TOTAL & 328 & 102 & 87 & 38 & 101 & 36 & 12 & $40.2 \%$ & $8.0 \%$ \\
\hline \multicolumn{10}{|c|}{ 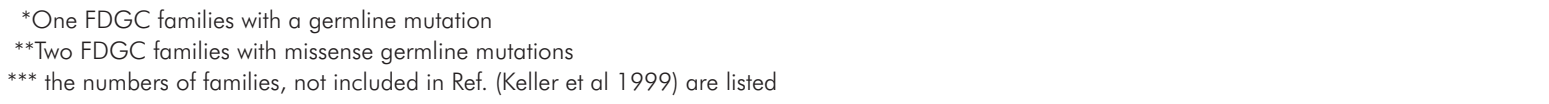 } \\
\hline
\end{tabular}

arise as a result of an inherited gastric cancer predisposition syndrome [7].

In formulating a definition of familial gastric cancer syndromes, a distinction must be made between the histopathological subtypes (diffuse or diffuse with glandular component/mixed versus intestinal) which segregate within families [8]. Gastric cancer was proved to be an inherited disease, primarily in families with aggregations of diffuse gastric cancer.

The syndrome of hereditary diffuse gastric cancer (HDGC) was defined by the International Gastric Cancer Linkage Consortium (IGCLC) [8], as any family that fits the following criteria: (1) two or more documented cases of diffuse gastric cancer in first/second degree relatives, with at least one diagnosed before the age of 50 , or (2) three or more cases of documented diffuse gastric cancer in first/second degree relatives, independently of age. The identification of the germline gene defect underlying HDGC came from segregation studies in early onset diffuse gastric cancer families [9-12]. Germline mutations of the $\mathrm{CDH} 1$ gene (EMBL/GenBank Data Libraries\# $\mathrm{CDH} 1$ - Z1 13009) resulting in $\mathrm{E}$-cadherin inactivation have been identified in HDGC (OMIM\# Gastric cancer - 137215). Families with aggregation of gastric cancer and index cases with diffuse gastric cancer but not fulfilling the IGCLC criteria for HDGC are termed familial diffuse gastric cancer (FDGC).

The criteria to define hereditary intestinal gastric cancer (HIGC) families were adjusted by the IGCLC depending on the incidence of gastric cancer in the 
Table 2. Details from all the $\mathrm{CDH} 1$ germline mutations described to date in familial gastric cancer

\begin{tabular}{|c|c|c|c|c|}
\hline $\mathrm{CDH} 1$ Mutation & Gene location & Mutation type & $\begin{array}{l}\text { Predicted premature } \\
\text { stop codon }\end{array}$ & Reference \\
\hline $45 \mathrm{ins} T$ & Exon 1 & Frameshift & Codon 32 & Oliveira et al, 2002 [32] \\
\hline $49-2 A>G$ & Intron 1 & Splice-site & Unknown & Richards et al, 1999 [1 1] \\
\hline 53delC & Exon 2 & Frameshift & Codon 32 & Humar et al, 2002 [89] \\
\hline $59 G>A$ & Exon 2 & Nonsense (W20X) & Codon 20 & Richards et al, 1999 [1 1] \\
\hline $70 G>T$ & Exon 2 & Nonsense (E24X) & Codon 24 & Guilford et al, 1999 [12] \\
\hline $185 G>T$ & Exon 3 & Missense (G62V) & Ns & Shinmura et al, 1999 [13] \\
\hline $187 \mathrm{C}>\mathrm{T}$ & Exon 3 & Nonsense (R63X) & Codon 63 & Gayther et al, 1998 [10] \\
\hline $190 \mathrm{C}>\mathrm{T}$ & Exon 3 & Nonsense (Q64X) & Codon 64 & Guilford et al, 1999 [12] \\
\hline $283 C>T$ & Exon 3 & Nonsense (Q95X) & Codon 95 & Dussaulx-Garin et al, 2001 [88] \\
\hline 372-377delC & Exon 3 & Frameshift & Codon 249 & Keller et al, 1999 [44] \\
\hline 382delC & Exon 3 & Frameshift & Codon 215 & Brooks-Wilson et al, in press [31] \\
\hline $531+1 G>A$ & Intron 5 & Splice-site & Unknown & Brooks-Wilson et al, in press [31] \\
\hline $586 \mathrm{G}>\mathrm{T}$ & Exon 5 & Nonsense (G196X) & Codon 196 & Guilford et al, 1999 [12] \\
\hline $731 A>G$ & Exon 6 & Missense (D244G) & Ns & Yoon et al, 1999 [85] \\
\hline $832 G>A$ & Exon 6 & Frameshift & $\begin{array}{c}\text { Codon } 281 \\
\text { Codon } 336+18 \mathrm{bp} \text { int } 7\end{array}$ & Oliveira et al, 2002 [32] \\
\hline $892 \mathrm{G}>\mathrm{A}$ & Exon 7 & Missense (A298T) & Ns & Brooks-Wilson et al, in press [31] \\
\hline $1003 C>T$ & Exon 7 & Nonsense (R335X) & Codon 335 & Jonsson et al, 2002 [25] \\
\hline $1008 \mathrm{G}>\mathrm{T}$ & Exon 7 & Splice-site & Codon 349 & Guilford et al, 1998 [9] \\
\hline $1018 A>G$ & Exon 8 & Missense (T340A) & Ns & Oliveira et al, 2002 [32] \\
\hline 1064ins T & Exon 8 & Frameshift & Codon 393 & Brooks-Wilson et al, in press [31] \\
\hline 1135del8ins5 & Exon 8 & Splice-site & Codon 386 & $\begin{array}{l}\text { Oliveira et al, } 2004 \text { [28]; } \\
\text { Brooks-Wilson et al, in press [31] }\end{array}$ \\
\hline $1137+1 G>A$ & Intron 8 & Donor splice-site & Unknown & Guilford et al, 1999 [12] \\
\hline 1212delC & Exon 9 & Frameshift & Codon 417 & Brooks-Wilson et al, in press [31] \\
\hline $1226 \mathrm{~T}>\mathrm{C}$ & Exon 9 & Missense (W409R) & Ns & Brooks-Wilson et al, in press [31] \\
\hline $1243 A>C$ & Exon 9 & Missense (1415L) & Ns & Wang et al, 2003 (two families) [27] \\
\hline $1460 T>C$ & Exon 10 & Missense (V487A) & Ns & Yoon et al, 1999 [85] \\
\hline 1472insA & Exon 10 & Frameshift & Codon 536 & Oliveira et al, 2002 [32] \\
\hline 1476delAG & Exon 10 & Frameshift & Codon 547 & Brooks-Wilson et al, in press [31] \\
\hline 1487del7 & Exon 10 & Frameshift & Codon 556 & Guilford et al, 1999 [12] \\
\hline $1565+1 G>T$ & Intron 10 & Splice-site & Unknown & Humar et al, 2002 [89] \\
\hline 1588insC & Exon 11 & Frameshift & Codon 536 & Guilford et al, 1999 [12] \\
\hline 1710delT & Exon 11 & Frameshift & Unknown & Humar et al, 2002 [89] \\
\hline
\end{tabular}


Table 2.

\begin{tabular}{|c|c|c|c|c|}
\hline $1711 \mathrm{ins} G$ & Exon 11 & Frameshift & Codon 587 & Gayther et al, 1998 [10] \\
\hline $1711+5 G>A$ & Intron 11 & Splice-site & Unknown & Brooks-Wilson et al, in press [31] \\
\hline 1779insC & Exon 12 & Frameshift & Codon 604 & Brooks-Wilson et al, in press [31] \\
\hline $1792 C>T$ & Exon 12 & Nonsense (R598X) & Codon 598 & Gayther et al, 1998, Humar et al, $2002[10,89]$ \\
\hline $1901 C>T$ & Exon 12 & Missense (A634V) & Codon 653 & Oliveira et al, in press [30] \\
\hline 2061 delTG & Exon 13 & Frameshift & Codon 783 & Brooks-Wilson et al, in press [31] \\
\hline $2095 C>T$ & Exon 13 & Nonsense (Q699X) & Codon 699 & Guilford et al, 1998 [9] \\
\hline $2195 \mathrm{G}>\mathrm{A}$ & Exon 14 & Missense (R732Q) & Ns & Brooks-Wilson et al, in press [31] \\
\hline $2295+5 G>A$ & Intron 14 & Splice-site & Unknown & Humar et al, 2002 [89] \\
\hline 2310delC & Exon 15 & Frameshift & Codon 783 & Brooks-Wilson et al, in press [31] \\
\hline 2382-2386ins C & Exon 15 & Frameshift & Codon 349 & Guilford et al, 1998 [9] \\
\hline $2396 C>G$ & Exon 15 & Missense (P799R) & Ns & Keller et al, 2004 [29] \\
\hline $2494 G>A$ & Exon 16 & Missense (V832M) & Ns & Yabuta et al, 2002 [26] \\
\hline
\end{tabular}

population. Thus, countries with a high incidence like Japan and Portugal should use the diagnostic criteria analogous to the Amsterdam criteria for HNPCC [13]: (1) at least three relatives should have intestinal gastric cancer and one of them should be a first degree relative of the other two; (2) at least two successive generations should be affected; (3) in one of the relatives, gastric cancer should be diagnosed before the age of 50. In countries with a low incidence (USA, UK) HIGC was defined as (1) at least two first/second degree relatives affected by intestinal gastric cancer, one diagnosed before the age of 50; or (2) three or more relatives with intestinal gastric cancer at any age. No germline genetic defect has been found to date in this type of predisposing disease.

Families with aggregations of gastric cancer and an index case with intestinal gastric cancer are termed familial intestinal gastric cancer (FIGC).

Families with aggregation of gastric cancer, but without histology available on the tumours are termed familial gastric cancer (FGC).

Patients who developed gastric cancer at an early age $(<50$ years old) without a familial history of gastric cancer were considered early onset gastric cancer patients.

\section{The $\mathrm{CDH} 1$ gene}

E-cadherin is a $120 \mathrm{kD}$ glycoprotein localised at adherens junctions of epithelial cells, where it mediates homophilic calcium-dependent cell-adhesion [14, 15]. The $\mathrm{CDH} 1$ gene maps to $16 \mathrm{q} 22.1$, comprises 16 exons spanning approximately $100 \mathrm{~kb}$ of genomic DNA which are transcribed into a $4.5 \mathrm{~Kb}$ mRNA [16]. The E-cadherin modular structure consists of five extracellular domains each $\sim 110$ aa in length, with conserved calcium-binding motifs, a transmembrane region and a cytoplasmic domain, which interacts with filaments of actin through catenins [17]. Disruption of the E-cadherin complex is expected to induce loss of cell-adhesion with a concomitant increased cell invasion [18, 19].

\section{E-cadherin and sporadic cancer}

Loss of E-cadherin function is one of the crucial steps for tumour progression in several types of human cancer. Despite what has been observed in other types of epithelial cancers, in which E-cadherin expression is down regulated without harbouring gene mutations, namely thyroid, skin, lung, ovary and colon, in sporadic diffuse gastric carcinoma $\mathrm{E}$-cadherin down regulation is often associated with gene mutation $[20,21,22]$. CDH1 mutations have been described not only in diffuse gastric cancers but also in a specific histological type of breast cancer namely infiltrative lobular breast cancers, another epithelial cancer in which neoplastic cells are dispersed in the stromal tissue [23]. Most of the somatic CDH7 mutations found in sporadic diffuse gastric carcinomas are missense and in-frame deletions [23]. In contrast to stomach, the mutations found in infiltrating lobular breast cancers were out-of-frame mutations, causing premature stop codons. In both models somatic mutations cluster in exons 7 to 9 , in the extracellular domain of the protein. 
Table 3. Details from $\mathrm{CDH} 1$ germline mutations described to date in early onset gastric cancer patients

\begin{tabular}{lcccl}
\hline CDH1 Mutation & Gene location & Mutation type & $\begin{array}{c}\text { Predicted premature } \\
\text { stop codon }\end{array}$ & Reference \\
\hline 1901C>T & Exon 12 & Missense (A634V) & Codon 653 & Suriano and Oliveira et al, 2003 [33] \\
\hline 1619insG & Exon 11 & Frameshift & Codon 547 & Keller et al, 2004 [29] \\
\hline
\end{tabular}

Inactivation of $\mathrm{CDH} 1$ in diffuse gastric cancer cell lines and primary lobular breast carcinomas is achieved by 2 genetic hits. Infiltrative lobular breast carcinomas show $\mathrm{LOH}$ at the $\mathrm{CDH} 1$ locus as a second hit. But in the majority of diffuse gastric cancer cases with $\mathrm{CDH} 1$ mutations it was demonstrated that hypermethylation of the $\mathrm{CDH} 1$ promoter region accounts for the inactivation of the second allele [24].

\section{Mutation of $\mathrm{CDH} 1$ in HDGC and Early-onset Gastric Cancer}

Germline truncating and missense mutations of the $\mathrm{CDH} 1$ gene resulting in $\mathrm{E}$-cadherin inactivation and/or segregating with the disease have been identified in hereditary diffuse gastric carcinoma. To date, forty eight families harbouring $\mathrm{CDH} 1$ germline mutations have been described, 41 HDGC (40\%) and 7 FDGC (8\%) (see Table 1 for details) [21, 25-31]. In these families, 45 different $\mathrm{CDH} 1$ germline mutations were found and dispersed along the gene (see Table 2 and Fig. 1 for details). The majority (76.0\%) of these $\mathrm{CDH} 1$ germline mutations are frameshift, splice-site and nonsense changes resulting in truncated non active proteins. Guilford et al described for the first time germline $\mathrm{CDH} 1$ mutations in a large percentage of $\mathrm{New}$ Zealand Maori HDGC families [9]. Shortly thereafter, $\mathrm{CDH} 1$ germline mutations were described in a broad range of ethnic backgrounds. $\mathrm{CDH} 1$ mutations were also found in a significant percentage of HDGC families of European and American origin [21]. In families of Asian ethnicity no truncating mutations have been identified to date [21]. In 24\% of the families $\mathrm{CDH} 1$ germline missense mutations have also been reported [26, 27, 29-33]. These missense mutations are also distributed along the gene, eight germline missense mutations cluster in the extracellular region of the protein, one in the transmembrane domain and two are localised in the intracellular domain of the protein (see Table 2 and Fig. 1 for details).

A total of 104 early-onset apparently sporadic gastric cancer patients were studied for $\mathrm{CDH} 1$ germline mutations. Eighty seven of them had diffuse type or mixed gastric cancer with a diffuse component. Only two of the 104 patients had germline $\mathrm{CDH} 1$ mutations (Table 3). These two mutations were identified in patients with diffuse gastric cancer [29, 33].

Initially it was reported that the mechanism of inactivation of the $\mathrm{CDH} 1$ wild-type allele in tumour cells from HDGC by families was either by promoter methylation or by somatic mutation [34]. The biallelic inactivation leads to diminished or absent E-cadherin immunoreactivity in the neoplastic cells [34]. Recently it was found in a Caucasian family with a $\mathrm{CDH} 1$ germline splice-site mutation in all members affected by gastric cancer, a CDH1 intragenic deletion of $\mathrm{CDH1}$, affecting at least exon 8, as the second hit in one of the tumours [28]. This observation highlights

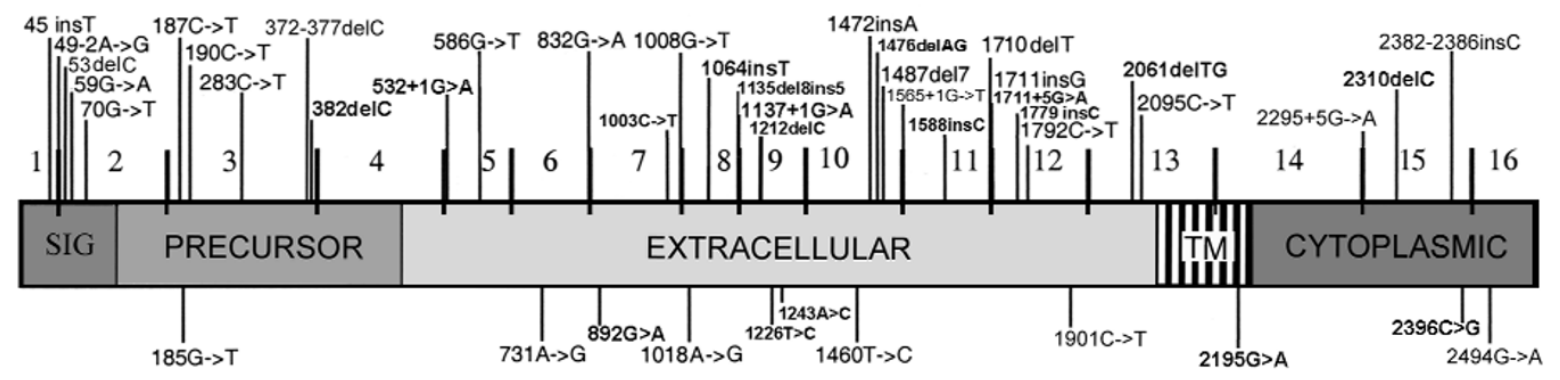

Fig. 1. Scheme of the $\mathrm{CDH1}$ gene with germline mutations described to date in HDGC. Truncating mutations are shown above and missense mutations below the gene. Sig: signal peptide; Precursor: protein precursor domain; TM: transmembrane domain; Cyto. Domain: protein cytoplasmic domain 
Table 4. Functional characterization of missense mutations found in gastric cancer probands

\begin{tabular}{llll}
\hline $\begin{array}{l}\text { CDH1 } \\
\text { Construct }\end{array}$ & Aggregation & Invasion & $\begin{array}{c}\text { Pathogenic } \\
\text { significance }\end{array}$ \\
\hline Wild type & Yes & No & Not applicable \\
\hline A298T & No & Yes & Yes \\
\hline T340A & No & Yes & Yes \\
\hline W409R & No & Yes & Yes \\
\hline A592T & Yes & No & No \\
\hline A617T & Yes & No & No \\
\hline A634V & No & Yes & Yes \\
\hline R732Q & No & Yes & Yes \\
\hline P799R & No & Yes & Yes \\
\hline V832M & No & Yes & Yes \\
\hline
\end{tabular}

the need of developing experimental protocols to identify, in the setting of HDGC families, the presence of germline or somatic intragenic deletions in $\mathrm{CDH}$, which are easily missed by mutation detection methods based on PCR of genomic DNA.

\section{Functional significance of $\mathrm{CDH} 1$ germline missense mutations}

The functional significance associated to $\mathrm{CDH} 1$ germline missense sequence variants is not straightforward. Moreover, due to the lethal nature of the disease there are rarely enough available affected individuals in any family to perform segregation analysis in families carrying germline missense sequence variants. The lack of such knowledge represents a major limitation for the clinical management of these patients and families.

To address this problem, a functional in vitro screen for gastric cancer missense mutations was created [33]. Cell-lines stably expressing the germline E-cadherin sequence variants were established and their effect on the protein ability to mediate cell-cell adhesion and suppress invasion was addressed. To date, we have analysed nine germline missense sequence variants and showed that some of these variants cause impaired or reduced cell-cell adhesion, increased cell motility and invasion, resulting in a scattered cell morphology and invasive phenotype similar to that observed in diffuse gastric carcinoma [29, 31, 33, 35-37] (see Table 4 for details).

In addition, it was shown that the effect of different E-cadherin germline missense mutations in cell morphology and motility was distinct, demonstrating the existence of a genotype-phenotype correlation between different E-cadherin mutations and cell behaviour, likely dependent on the specific E-cadherin domain affected by each mutation [38].

The aforementioned studies indicate that functional assays should be used as an adjunct in deciding on the potential pathogenic role of germline sequence variants, with significant potential to help clinical counselling of the $\mathrm{CDH} 1$ mutation carriers.

\section{$\mathrm{CDH} 1$ polymorphisms}

There is an increasing number of manuscripts reporting $\mathrm{CDH} 1$ sequence variants in gastric cancer families and also in controls (see Table 5 for details). Two good examples of these sequence variants are single nucleotide polymorphisms located at the promoter region of $\mathrm{CDH1}$, the $-347 \mathrm{G}->\mathrm{GA}$ and the $-160 \mathrm{C} / \mathrm{A}$. Both sequence variants were described to affect the transcriptional activity of $\mathrm{CDH}$.

The -347G->GA single nucleotide polymorphism was shown to down regulate the transcriptional activity of the $\mathrm{E}$-cadherin gene by measuring the promoter activity of the -347G->GA polymorphism. The GA allele decreased the transcriptional efficiency by 10 -fold $(p<0.001)$ and had a weak transcription factor binding compared to the $G$ allele [39]. In a case-control study performed in a Korean population of 170 individuals (28 probands from gastric cancer families and 142 normal controls) the $-347 \mathrm{G} / \mathrm{GA}$ heterozygous or GA homozygous was associated with FGC patients $(p<0.05)$ compared with the $G$ homozygous genotype [39].

The A-allele of the -160C/A polymorphism was shown to decrease the transcriptional efficiency by $68 \%$ compared with the $\mathrm{C}$-allele, down regulating $\mathrm{E}$-cadherin expression [40]. Wu and colleagues [41] suggested that individuals who have inherited two copies of the A-allele that reduce transcription of $\mathrm{CDH} 1$ may have a decreased risk of developing gastric cancer in a Taiwanese population. However, no consistent data has been reported about the association between the $-160 \mathrm{C} / \mathrm{A}$ $\mathrm{CDH} 1$ sequence variant and gastric cancer. In a case-control study performed in an Italian population this variant was associated with an increased susceptibility to diffuse gastric cancer. The frequency of the $-160 \mathrm{~A}$ allele was significantly higher $(\mathrm{P}<0.005)$ in 53 diffuse gastric cancer cases compared to 70 matched controls. The odds ratio associated with the A-allele was 2.27 for CA-heterozygotes (95\% Cl 1.16-4.44) and 7.84 for AAhomozygotes (95\% Cl 2.89-21.24) [42]. However, these results were not confirmed in a large series of gastric cancer patients and control populations from Portugal, 
Table 5. Polymorphisms identified in $\mathrm{CDH1}$ in gastric cancer probands and normal controls reported to date

\begin{tabular}{|c|c|c|c|c|c|c|}
\hline $\begin{array}{l}\text { Sequence } \\
\text { variant }\end{array}$ & $\begin{array}{l}\text { Gene } \\
\text { location }\end{array}$ & Codon & Effect & $\%$ patients & $\%$ controls & Reference \\
\hline$-71 C>G$ & Promoter & & Unknown & $1 / 13(7.7 \%)$ & $2 / 51(3.9 \%)$ & Avizienyte et al, 2000 [87] \\
\hline$-160 C>A$ & Promoter & & See text & $\begin{array}{c}17 / 32(53.1 \%) \\
2 / 5(40 \%) \\
7 / 28(25 \%) \\
31 / 87(35.6 \%)\end{array}$ & $\begin{array}{c}63 / 114(55.3 \%) \\
38 / 94(40.4 \%) \\
32 / 142(22.5 \%) \\
18 / 50(36 \%)\end{array}$ & $\begin{array}{l}\text { Oliveira et al, } 2002 \text { [32] } \\
\text { Humar et al, } 2002[89] \\
\text { Shin et al, } 2004 \text { [39] } \\
\text { Wang et al, } 2003 \text { [27] }\end{array}$ \\
\hline$-347 G>G A$ & Promoter & & See text & $12 / 28(42.9 \%)$ & 39/142 (27.5\%) & Shin et al, 2004 [39] \\
\hline $48+6 \mathrm{~T}>\mathrm{C}$ & Intron 1 & & Unknown & $\begin{array}{c}5 / 13(38 \%) \\
11 / 28(39.3 \%) \\
1 / 10(10 \%) \\
5 / 17(29.4 \%)\end{array}$ & $\begin{array}{c}18 / 51(35 \%) \\
27 / 100(27 \%) \\
75 / 350(21.4 \%) \\
\text { nd }\end{array}$ & $\begin{array}{l}\text { Avizienyte et al, } 2000 \text { [87] } \\
\text { Oliveira et al, } 2002 \text { [32] } \\
\text { Humar et al, } 2002 \text { [89] } \\
\text { Yabuta et al, } 2002 \text { [26] }\end{array}$ \\
\hline $531+10 G>C$ & Intron 4 & & Unknown & $\begin{array}{l}2 / 34(5.9 \%) \\
\text { ns } \\
\text { ns }\end{array}$ & $\begin{array}{l}\text { nd } \\
\text { nd } \\
\text { nd }\end{array}$ & $\begin{array}{l}\text { Oliveira et al, } 2002 \text { [32] } \\
\text { Guilford et al, } 1999 \text { [12] } \\
\text { Gayther et al, } 1998 \text { [10] }\end{array}$ \\
\hline $532-18 C>T$ & Intron 4 & & Unknown & $\begin{array}{l}2 / 66(3.0 \%) \\
2 / 34(5.9 \%)\end{array}$ & $\begin{array}{l}0 / 100(0 \%) \\
1 / 50(2.0 \%)\end{array}$ & $\begin{array}{l}\text { Suriano and Oliveira et al, } 2003 \text { [33] } \\
\text { Keller et al, } 2004 \text { [29] }\end{array}$ \\
\hline $918 C>T$ & Exon 7 & 306 & Silent & $1 / 34(2.9 \%)$ & nd & Oliveira et al, 2002 [32] \\
\hline $1029 C>G$ & Exon 8 & 343 & Silent & $1 / 34(2.9 \%)$ & nd & Oliveira et al, 2002 [32] \\
\hline $1774 G>A$ & Exon 12 & 592 & A592T & $1 / 34(2.9 \%)$ & $1 / 50(2.0 \%)$ & Keller et al, 2004 [29] \\
\hline $1849 G>A$ & Exon 12 & 617 & A617T & $2 / 66(3 \%)$ & $2 / 193(1 \%)$ & Suriano and Oliveira et al, 2004 [33] \\
\hline $1896 C>T$ & Exon 12 & 632 & Silent & $\begin{array}{c}1 / 34(2.9 \%) \\
n s\end{array}$ & $\begin{array}{l}5 / 100(5 \%) \\
\text { nd }\end{array}$ & $\begin{array}{l}\text { Oliveira et al, } 2002 \text { [32] } \\
\text { Gayther et al, } 1998 \text { [10] }\end{array}$ \\
\hline $1937-13 T>C$ & Intron 12 & & Unknown & $\begin{array}{l}2 / 27(7.4 \%) \\
n s\end{array}$ & $\begin{array}{l}25 / 100(25 \%) \\
\text { nd }\end{array}$ & $\begin{array}{l}\text { Oliveira et al, } 2002[32] \\
\text { Guilford et al, 1998, } 1999[9,12]\end{array}$ \\
\hline $1937-27 \mathrm{~T}>\mathrm{G}$ & Intron 12 & & Unknown & ns & nd & Guilford et al, 1999 [12] \\
\hline $2076 C>T$ & Exon 13 & 692 & Silent & $\begin{array}{c}8 / 13(61.5 \%) \\
15 / 27(55.6 \%) \\
1 / 5(20 \%) \\
7 / 16(43.8 \%) \\
\text { ns } \\
\text { ns } \\
\text { ns } \\
82 / 87(94.3 \%)\end{array}$ & $\begin{array}{c}\text { nd } \\
29 / 100 \text { (59.0\%) } \\
\text { nd } \\
\text { nd } \\
\text { nd } \\
\text { nd } \\
\text { ns } \\
48 / 50(96 \%)\end{array}$ & $\begin{array}{l}\text { Avizienyte et al, } 2000[87] \\
\text { Oliveira et al, } 2002[32] \\
\text { Richards et al, } 1999[11] \\
\text { lida et al, 1999 [86] } \\
\text { Guilford et al, 1998, 1999 [9, 12] } \\
\text { Gayther et al, } 1998[10] \\
\text { Yabuta et al, } 2002[26] \\
\text { Wang et al, } 2003 \text { [27] }\end{array}$ \\
\hline $2253 C>T$ & Exon 14 & 751 & Silent & ns & ns & Yabuta et al, 2002 [26] \\
\hline $2292 C>T$ & Exon 14 & 764 & Silent & $1 / 34(2.9 \%)$ & nd & Oliveira et al, 2002 [32] \\
\hline $2634 C>T$ & Exon 16 & 878 & Silent & $1 / 34(2.9 \%)$ & nd & Oliveira et al, 2002 [32] \\
\hline
\end{tabular}

nd, Not done; ns, Not specified.

Canada and Germany who have found no significant evidence for an association between stomach cancer and the $-160 \mathrm{C} / \mathrm{A}$ polymorphism in the promoter of $\mathrm{CDH} 7$. In this report a total of 899 individuals (433 patients and 466 controls) were analysed. The genotype frequencies did not differ significantly between cases and controls, and the genotype-specific risks were not significantly different from unity, with an odds ratio for heterozygotes compared with the common homozygote of 1.3 (95\% $\mathrm{Cl} 0.98-1.8)$ and $1.2(0.68-2.0)$ for rare homozygotes compared with common homozygotes [43].

In summary, it is mandatory to clarify the functional 
Table 6. Candidate genes analysed in gastric cancer families

\begin{tabular}{lccll}
\hline $\begin{array}{l}\text { Candidate } \\
\text { gene }\end{array}$ & $\begin{array}{c}\text { No } \\
\text { of families } \\
\text { analysed }\end{array}$ & $\begin{array}{c}\text { Germline } \\
\text { mutations }\end{array}$ & Observations & Reference \\
\hline TP53 & 66 & $\begin{array}{l}471 C>\text { G (FGC) } \\
847 C>\text { (FDGC) }\end{array}$ & $\begin{array}{l}\text { Family reclassified as Li-Fraumeni } \\
\text { Highly conserved residue (Arg 283) }\end{array}$ & $\begin{array}{l}\text { Oliveira et al, in press [30] } \\
\text { Keller et al, 2004 [29] }\end{array}$ \\
\hline SMAD4 & 32 & 0 & Probably not relevant for familial gastric cancer & Oliveira et al, in press [30] \\
\hline Caspase 10 & 32 & 0 & Probably not relevant for familial gastric cancer & Oliveira et al, in press [30] \\
\hline RUNX3 & 34 & 0 & Probably not relevant for familial gastric cancer & Keller et al, 2004 [29] \\
\hline HPP1 & 34 & 0 & Probably not relevant for familial gastric cancer & Keller et al, 2004 [29] \\
\hline
\end{tabular}

relevance of the $A$ allele in vivo and to disclose the association of the A/A genotype with $G C$ in larger epidemiologic studies.

\section{Other cancers in HDGC families}

In the $\mathrm{CDH} 1$ positive families, family members show other types of malignancy besides diffuse gastric cancer. Breast, colon (namely signet ring cell cancer of the colon), prostate and ovarian carcinomas have been shown to occur in families carrying $\mathrm{CDH} 1$ germline mutations suggesting that non-gastric malignancies can be associated with HDGC [21, 31].

Importantly, breast carcinoma, in particular of the lobular type, has been associated to a positive history of gastric carcinoma [44]. There was reported a gastric cancer patient carrying a germline mutation of $\mathrm{CDH} 1$ who had a mother affected with bilateral breast carcinoma at the age of 49 [29]. An overrepresentation of this tumour type in families with $E$-cadherin germline mutations has been demonstrated [45]. In a recent study, 17 cases of breast cancer were found in families carrying $\mathrm{CDH} 1$ germline mutations, three of which were histologically confirmed as lobular breast carcinomas. This data highlights the need for screening of $\mathrm{CDH} 1$ germline mutations in families with both types of malignancy, diffuse gastric carcinoma and lobular breast carcinoma occurring in the same family.

\section{Familial Gastric Cancer and genes involved in other inherited syndromes}

Gastric cancer might also be seen as part of the tumour spectrum in other inherited cancer predisposition syndromes. In particular, gastric cancer has been identified as part of the HNPCC syndrome [46]. As a consequence, the tumours of patients with germline MMR deficiency exhibit a particular phenotype called
MSI-H, characterised by a global instability phenomenon affecting microsatellite repetitive sequences $[47,48]$. The MSI-H phenotype has been extensively used to pre-screen tumours in cases in which patients should be analysed for hMLH1 and hMSH2 [47]. Recently, two tumours from familial gastric cancer probands were detected with MSI-H (one with HDGC and the other with familial gastric cancer). In these two probands germline mutations in $\mathrm{hMLH} 1$ and hMSH2 were excluded, though other mismatch repair genes may be involved [30].

Gastric cancer has also been recognised as a component of other hereditary cancer syndromes, such as the Li-Fraumeni syndrome [49]. Most of the cases harbouring germline mutations of the p53 gene have been found in approximately $70 \%$ of the families with Li-Fraumeni syndrome. Recently, two gastric cancer families with p53 germline mutations were identified. One mutation was previously described in a Li-Fraumeni kindred and the other was localised in a highly conserved region of p53 [29, 30] (Table 6). In these gastric cancer families with p53 germline mutations, gastric, liver, pancreatic, colon cancers and leukaemia occurred in different members of the families [29, 30]. The presence of p53 germline mutations in families with a predominance of gastric cancer strengthens the need for p53 mutation screening in families with aggregations of gastric cancer and no $\mathrm{CDH} 1$ mutations.

In addition to HNPCC and Li-Fraumeni syndrome, stomach cancer can also occur in breast and ovarian cancer families. Recently, twenty nine families harbouring gastric and breast malignancies were screened for germline mutations in BRCA2 and in six of the 29 (20.7\%), three frameshift mutations and three missense mutations were identified [50]. Moreover, a BRCA2 mutation was found in eight of 34 women with ovarian cancer and a family history of stomach cancer [51]. In gastric cancer families with an excess of breast and ovarian tumours, lacking CDH1, p53 or MSI-H tumour phenotype, BRCA2 is likely to be a candidate gene. 


\section{Other candidate genes in Familial Gastric Cancer}

In kindreds negative for $\mathrm{CDH} 1$ or p53 germline mutations, other genes are probably involved. We will address RUNX3, HPP 1, Caspase-10 and SMAD4, which have been shown to be involved in gastric cancer development (mutated in sporadic gastric carcinoma or associated with gastric cancer phenotype in knockout models).

Putative tumour suppressor genes, which are commonly inactivated in sporadic gastric cancers, could also represent good candidate susceptibility genes to familial gastric cancer. RUNX3, which belongs to the family of runt domain transcription factors, as well as HPP 1, encoding a cell surface receptor, which is suggested to play multiple roles in cell growth, maturation and adhesion, have recently been shown to be inactivated by promoter hypermethylation at a high frequency in gastric cancer $[52,53]$. Moreover, in the Runx3/Pebp2alphaC null mouse gastric mucosa exhibits hyperplasias due to stimulated proliferation and suppressed apoptosis in epithelial cells. Gastric cancer families that were screened for RUNX3 and $H P P 1$, do not show germline mutations in both genes, suggesting that RUNX3 and HPP1 are not important alternative gastric cancer predisposition genes [29]. In $3 \%$ of sporadic gastric carcinomas alterations of caspase-10 were described [54]. In vitro expression studies have shown that cells carrying caspase- 10 mutations harbour impaired caspase-10-mediated apoptosis, suggesting that somatic alterations of the caspase-10 gene might contribute to the pathogenesis of gastric cancers through the loss of their apoptotic function [54]. Germline mutations in caspase- 10 were recently screened in families with gastric cancer and early-onset gastric carcinoma patients, but only a high frequency of sequence variants was found. All variants showed similar frequencies in cases (gastric cancer probands) and in control populations demonstrating its polymorphic nature [30].

In knockout studies SMAD4 heterozygous mice revealed the presence of foci of signet ring carcinoma cells in the stomach [55]. Germline mutations in the SMAD4 gene were described in a minority of hereditary juvenile polyposis (JPS) [56, 57]. The tumour suppressor gene, SMAD4, is a transcription activator that binds specific DNA sequences and whose nuclear localisation is induced after exposure to TGF $\beta$. This gene was searched for germline mutations in gastric cancer families but only sequence variants were found. These sequence variants were either silent or intronic alterations that were present with the same frequency in normal controls pointing to its polymorphic nature [30].
In summary, RUNX3, HPP1, Caspase-10 and SMAD4 can be ruled out as major gastric cancer predisposition genes in families with an excess of gastric carcinoma (see Table 6 for details).

\section{Genetic counselling in HDGC}

The IGCLC recommends pre- and post-test genetic counselling for families that either meet or exceed the minimum requirements for HDGC [8].

Testing of asymptomatic at-risk adults for HDGC is available only after an affected family member has been tested and a mutation found. Testing of an asymptomatic at-risk individual is considered predictive testing, not diagnostic testing. Lynch et al [58] describe the genetic counselling process they followed with a large kindred with HDGC. Relevant issues should be discussed with family members seeking predictive testing for HDGC. Discussion should include: (1) the genetics of cancer development and HDGC; (2) the individual's knowledge of HDGC; (3) the individual's reasons for requesting the test; (4) the individual's understanding of the risk for having inherited the mutation based on a family history of HDGC; (5) availability of molecular genetic testing; (6) cancer risk if the individual has inherited the mutation; (7) recommendations for cancer screening and prophylactic surgery; and (8) the possible social impact of positive and negative test results.

Genetic testing in children has always been a controversial issue. Since there have been reports of patients diagnosed with HDGC under the age of 18, it has been suggested that genetic testing in children may be beneficial [8]. Overall, a request from parents for testing of asymptomatic at-risk children requires sensitivity and understanding and thorough rigorous counselling for both the parents and child.

Requests for prenatal testing for conditions such as HDGC that do not affect intellect and have some available treatment are uncommon. Differences in perspective may exist among medical professionals and in families regarding the use of prenatal testing, particularly if the testing is being considered for the purpose of pregnancy termination rather than early diagnosis. Although most centres would consider decisions about prenatal testing to be the choice of the parents, careful discussion of these issues is appropriate.

\section{Helicobacter pylori infection and Familial Gastric Cancer}

Among the possible causes of familial aggregation of gastric cancer, exposure to similar environmental factors 
such as $H$. pylori infection may contribute to a higher number of affected individuals within the same family.

$H$. pylori is one of the most common chronic infections in a man, and once acquired early in childhood and if left untreated, persists for the host's lifetime [59]. Risk factors for H. pylori acquisition include a low socioeconomic status, household crowding, country of origin and ethnicity, and transmission occurs from person to person [60]. Intrafamilial clustering of the infection also reinforces the importance of person-to-person transmission [61].

A large number of studies provided evidence for the aetiological role of $H$. pylori in gastric carcinoma, and the infection significantly increases the risk of developing both subtypes of gastric carcinoma [6265]. Despite the well established role of $H$. pylori as a risk factor for gastric cancer, the mechanism of carcinogenesis is still not very clear. The first consequence of $H$. pylori infection is the induction of chronic superficial gastritis. The initiation and promotion of gastric neoplasia may occur via disruption of the epithelial cell proliferation/apoptosis balance and direct damage to host-cell DNA through the synthesis of reactive oxygen species $[66,67]$.

Nevertheless, only a small fraction of infected individuals develop gastric cancer. This probably depends on a combination of factors, including variation in bacterial pathogenicity. $H$. pylori is genomically diverse and strain differences in virulence factors, including the cag pathogenicity island and the vacuolating cytotoxin, have an important role in the development of gastric carcinoma [68-70].

Within the context of familial gastric cancer, it has been shown that first degree relatives of gastric cancer patients have an increased prevalence of $H$. pylori infection [71-73]. Furthermore, $H$. pylori-infected first degree relatives of gastric cancer patients have an increased prevalence of histological and physiological preneoplastic changes, such as atrophic gastritis, intestinal metaplasia and high levels of hypochlorhydria [71, 74].

Although it has not been proven that the eradication of $\mathrm{H}$. pylori will result in protection against gastric cancer in first degree relatives of gastric cancer patients, this group is at a significantly higher risk than the general population [72, 74, 75]. Therefore, international consensus guidelines strongly recommended $\mathrm{H}$. pylori eradication in first degree relatives of gastric cancer patients [75].

In summary, although familial aggregation of gastric cancer may be mediated by familial clustering of $H$. pylori infection [61], the infection alone cannot explain all of the family aggregation of gastric cancer. Additional genetic and environmental risk factors are likely to contribute to this finding.

\section{Low penetrance genes and genetic susceptibility to gastric cancer}

The low frequency of germline mutations in high penetrance genes in familial gastric cancer may be related to an increased susceptibility of these patients to gastric cancer due to low penetrance predisposing genes in association with environmental factors. Patients infected with $H$. pylori are at an increased risk of developing gastric carcinoma [62]. The risk of developing this type of tumour relates to the physiological and histological changes that $H$. pylori infection induces in the stomach $[76,77]$. Although there is evidence showing that $H$. pylori infection plays a crucial role in the pathogenesis of gastric carcinoma, a striking difference exists between the number of infected individuals and the number that go on to develop malignancy. Hence, progression towards disease is likely to depend on the combined effects of bacterial pathogenicity, host susceptibility and environmental factors.

The IL IB-51 7*T and IL IRN*2 alleles - which are putatively associated with increased levels of IL $1 \beta$ production [78, 79] - and the TNFA-308*A allele which is thought to increase the production of TNF $\alpha$ [80] - have been found to confer an increased risk of development of gastric carcinoma $[69,81,82]$. The combined effect of pro-inflammatory host genetic polymorphisms in the ILIB, ILIRN and TNFA genes in the risk of gastric carcinoma development has also been investigated. For gastric carcinoma the odds of developing disease increased with the number of high-risk genotypes. Individuals carrying the three high-risk genotypes are at an increased risk of gastric carcinoma with an $\mathrm{OR}$ of $9.7(95 \% \mathrm{Cl} 2.6-36.0)$ [83]. Very similar findings were also reported by El-Omar and colleagues [84].

Results on record support the hypothesis that the extent of gastric mucosal injury may be related to $H$. pylori strain differences, inflammatory responses governed by host genetics, and interactions between host and bacterial determinants. The combination of these factors, favouring a set of responses with higher magnitude, can eventually result in hypochlorhydria, corpus atrophy, and an increased risk of gastric carcinoma. In this context, the $I L 1 B, I L 7 R N$ and TNFA genes would play a role in gastric carcinogenesis as low penetrance genes.

\section{In conclusion}

Sporadic diffuse gastric cancer cases harbour somatic mutations within the $\mathrm{CDH} 1$ gene of the truncating and missense type, clustered in exons seven to nine. Similarly, approximately $40 \%$ of the families that fulfil the criteria 
for HDGC show germline mutations of the same gene, $80 \%$ of which are of the truncating type and evenly distributed along the gene. In $\sim 20 \%$ of cases, germline $\mathrm{CDH} 1$ missense mutations were found and their functional significance was determined by functional assays using an in vitro cell model system. p53 was found to be mutated in families with an excess of gastric cancer and negative for $\mathrm{CDH} 1$ germline mutations indicating the need of p53 screen in these types of families. These p53 germline mutation carriers should have a distinct clinical follow-up. It is of great importance to perform an early and comprehensive screening for $\mathrm{CDH} 1$ mutations in families at an increased risk of developing diffuse gastric cancer, to allow adequate genetic counselling in these families. Efforts must be made to disclose the genetic basis underlying HDGC in families that lack $\mathrm{CDH} 1$ mutations. Familial aggregation of gastric cancer, in the absence of mutations in high penetrance genes, may be in part explained by familial clustering of $\mathrm{H}$. pylori infection in combination with an increased host susceptibility.

\section{Acknowledgements}

Raquel Seruca would like to thank all the young members of IPATIMUP that were involved in the work reported herein.

\section{References}

1. Howson CP, Hiyama T and Wynder EL. The decline in gastric cancer: epidemiology of an unplanned triumph. Epidemiol Rev 1986; 8: 1-27

2. La Vecchia C, Lucchini F, Negri E, Boyle P, Maisonneuve P and Levi F. Trends of cancer mortality in Europe, 1955-1989: I, Digestive sites. Eur J Cancer 1992; 28 (1): 132-235.

3. Carneiro F. Classification of gastric carcinomas. Curr Diag Pathol 1997; 4: 51-9.

4. Laurén P. The two histological main types of gastric carcinoma: diffuse and so-called intestinal-type carcinoma. An attempt at a histo-clinical classification. Acta Pathol Microbiol Scand 1965; 64: 31-49.

5. Goldgar DE, Easton DF, Cannon-Albright LA and Skolnick MH. Systematic population-based assessment of cancer risk in first-degree relatives of cancer probands. J Natl Cancer Inst 1994; 86 (21): 1600-8.

6. Zanghieri G, Di Gregorio C, Sacchetti C, Fante R, Sassatelli R, Cannizzo G, Carriero A and Ponz de Leon M. Familial occurrence of gastric cancer in the 2-year experience of a population-based registry. Cancer 1990; 66 (9): 2047-51.

7. Palli D, Galli M, Caporaso NE, Cipriani F, Decarli A, Saieva C, Fraumeni JF Jr and Buiatti E. Family history and risk of stomach cancer in Italy. Cancer Epidemiol Biomarkers Prev 1994; 3 (1): 15-8.

8. Caldas C, Carneiro F, Lynch HT, Yokota J, Wiesner GL, Powell $S M$, Lewis $F R$, Huntsman DG, Pharoah PD, Jankowski JA, MacLeod P, Vogelsang H, Keller G, Park KG, Richards FM, Maher ER, Gayther SA, Oliveira C, Grehan N, Wight D, Seruca R, Roviello F, Ponder BA and Jackson CE. Familial gastric cancer: overview and guidelines for management. J Med Genet 1999; 36 (12): 873-80.
9. Guilford P, Hopkins J, Harraway J, McLeod M, McLeod N, Harawira P, Taite H, Scoular R, Miller A and Reeve AE. E-cadherin germline mutations in familial gastric cancer. Nature 1998; 392 (6674): 402-5.

10. Gayther SA, Gorringe KL, Ramus SJ, Huntsman D, Roviello F, Grehan N, Machado JC, Pinto E, Seruca R, Halling K, MacLeod P, Powell SM, Jackson CE, Ponder BA and Caldas C. Identification of germ-line E-cadherin mutations in gastric cancer families of European origin. Cancer Res 1998; 58 (18): 4086-9.

11. Richards FM, McKee SA, Rajpar MH, Cole TR, Evans DG, Jankowski JA, McKeown C, Sanders DS and Maher ER. Germline E-cadherin gene ( $\mathrm{CDH} 1)$ mutations predispose to familial gastric cancer and colorectal cancer. Hum Mol Genet 1999; 8 (4): 607-10.

12. Guilford PJ, Hopkins JB, Grady WM, Markowitz SD, Willis J, Lynch H, Rajput A, Wiesner GL, Lindor NM, Burgart LJ, Toro TT, Lee D, Limacher JM, Shaw DW, Findlay MP and Reeve AE. Ecadherin germline mutations define an inherited cancer syndrome dominated by diffuse gastric cancer. Hum Mutat 1999; 14 (3): 249-55.

13. Shinmura K, Kohno T, Takahashi M, Sasaki A, Ochiai A, Guilford P, Hunter A, Reeve AE, Sugimura $H$, Yamaguchi N and Yokota J. Familial gastric cancer: clinicopathological characteristics, RER phenotype and germline p53 and E-cadherin mutations. Carcinogenesis 1999; 20 (6): 1127-31.

14. Shore EM and Nelson WJ. Biosynthesis of the cell adhesion molecule uvomorulin (E-cadherin) in Madin-Darby canine kidney epithelial cells. J Biol Chem 1991; 266 (29): 19672-80.

15. Shapiro L, Fannon AM, Kwong PD, Thompson A, Lehmann MS, Grubel G, Legrand JF, Als-Nielsen J, Colman DR and Hendrickson WA. Structural basis of cell-cell adhesion by cadherins. Nature 1995; 374 (6520): 327-37.

16. Berx G, Cleton-Jansen AM, Nollet F, de Leeuw WJ, van de Vijver $M$, Cornelisse $C$ and van Roy F. E-cadherin is a tumour/invasion suppressor gene mutated in human lobular breast cancers. EMBO J 1995; 14 (24): 6107-15.

17. Leckband D and Sivasankar S. Mechanism of homophilic cadherin adhesion. Curr Opin Cell Biol 2000; 12 (5): 587-92.

18. Christofori $G$ and Semb H. The role of the cell-adhesion molecule E-cadherin as a tumour-suppressor gene. Trends Biochem Sci 1999; 24 (2): 73-6.

19. Van Aken E, De Wever O, Correia da Rocha AS and Mareel M. Defective E-cadherin/catenin complexes in human cancer. Virchows Arch 2001; 439 (6): 725-51.

20. Becker KF, Atkinson MJ, Reich U, Becker I, Nekarda H, Siewert $J R$ and Hofler $\mathrm{H}$. E-cadherin gene mutations provide clues to diffuse type gastric carcinomas. Cancer Res 1994; 54 (14): 3845-52.

21. Oliveira C, Seruca R and Caldas C. Genetic screening for hereditary diffuse gastric cancer. Expert Rev Mol Diagn 2003; 3 (2): 201-15.

22. Soares P, Berx G, van Roy F and Sobrinho-Simoes M. E-cadherin gene alterations are rare events in thyroid tumors. Int J Cancer 1997; 70 (1): 32-8.

23. Berx G, Becker KF, Hofler H and van Roy F. Mutations of the human E-cadherin (CDH1) gene. Hum Mutat 1998; 12 (4): 226-37.

24. Machado JC, Oliveira C, Carvalho R, Soares P, Berx G, Caldas C, Seruca R, Carneiro F and Sobrinho-Simoes M. E-cadherin gene $(\mathrm{CDH} 1)$ promoter methylation as the second hit in sporadic diffuse gastric carcinoma. Oncogene 2001; 20 (12): 1525-8.

25. Jonsson BA, Bergh A, Stattin P, Emmanuelsson M and Gronberg $\mathrm{H}$. Germline mutations in E-cadherin do not explain association of hereditary prostate cancer, gastric cancer and breast cancer. Int J Cancer 2002; 98 (6): 838-43. 
26. Yabuta T, Shinmura K, Tani M, Yamaguchi S, Yoshimura K, Kata H, Nakajima T, Mochiki E, Tsujinaka T, Takami M, Hirose K, Yamaguchi A, Takenoshita S and Yokota J. E-cadherin gene variants in gastric cancer families whose probands are diagnosed with diffuse gastric cancer. Int J Cancer 2002; 101 (5): 434-41.

27. Wang Y, Song JP, Ikeda M, Shinmura K, Yokota J and Sugimura $H$. Ile-Leu substitution (1415L) in germline E-cadherin gene $(\mathrm{CDH} 1)$ in Japanese familial gastric cancer. Jpn J Clin Oncol 2003; 33 (1): 17-20.

28. Oliveira C, de Bruin J, Nabais S, Ligtenberg M, Moutinho C Nagengast FM, Seruca R, van Krieken H and Carneiro F. Intragenic deletion of $\mathrm{CDH} 1$ as the inactivating mechanism of the wild-type allele in a HDGC tumour. Oncogene 2004; 23 (12): 2236-40.

29. Keller G, Vogelsang H, Becker I, Plaschke S, OH K, Suriano G, Mateus AR, Seruca R, Biedermann K, Hundsman D, Döring C Holinski-Feder E, Neutzling A, Siewert JR and Höfler H. Germline mutations of the E-cadherin (CDH1) and TP53 genes rather than of RUNX3 and HPP1 contribute to genetic predisposition in german gastric cancer patients. J Med Genet 2004; 41 (6): E89.

30. Oliveira C, Ferreira P, Nabais S, Campos L, Ferreira A, Cirnes L, Alves CC, Veiga I, Fragoso M, Regateiro F, Dias LM, Moreira $H_{\text {, }}$ Suriano G, Machado JC, Lopes C, Castedo S, Carneiro F and Seruca R. E-Cadherin (CDH1) and TP53 rather than SMAD4 and Caspase-10 germline mutations contribute to genetic predisposition in Portuguese gastric cancer patients. Eur J Cancer In press.

31. Brooks-Wilson AR, Kaurah P, Suriano G, Leach S, Senz J, Grehan N, Buttefield YSN, Jeyes J, Schinas J, Bacani J, Kelsey M, Ferreira P, MacGillivray B, MacLeod P, Micek M, Ford J, Foulkes W, Australie K, Greenberg C, LaPointe M, Gilpin CR, Nikkel S, Gilchrist D, Hughes R, Jackson C, Monaghan KG, Oliveira MJ, Seruca R, Gallinger S, Caldas C and Huntsman DG. Germline E-Cadherin Mutations in Hereditary Diffuse Gastric Cancer: Assessment of 42 New Families and Review of Genetic Screening Criteria. J Med Genet In press.

32. Oliveira C, Bordin MC, Grehan N, Huntsman D, Suriano G, Machado JC, Aaltonen L, Jackson CE, Seruca R and Caldas C. Screening of E-Cadherin in gastric cancer families reveals germ-line mutations only in hereditary diffuse gastric cancer kindred. Hum Mutat 2002; 19 (5): 510-517.

33. Suriano G, Oliveira C, Ferreira P, Machado JC, Bordin MC, De Wever O, Bruyneel EA, Moguilevsky N, Grehan N, Porter TR, Richards FM, Hruban RH, Roviello F, Huntsman D, Mareel M, Carneiro F, Caldas $\mathrm{C}$ and Seruca R. Identification of $\mathrm{CDH} 1$ germline missense mutations associated with functional inactivation of the $\mathrm{E}$-cadherin protein in young gastric cancer probands. Hum Mol Genet 2003; 12 (5): 575-582.

34. Grady WM, Willis J, Guilford PJ, Dunbier AK, Toro TT, Lynch H, Wiesner G, Ferguson K, Eng C, Park JG, Kim SJ and Markowitz $\mathrm{S}$. Methylation of the $\mathrm{CDH} 1$ promoter as the second genetic hit in hereditary diffuse gastric cancer. Nat Genet 2000; 26 (1): 16-17.

35. Handschuh G, Luber B, Hutzler P, Hofler H and Becker KF. Single amino acid substitutions in conserved extracellular domains of E-cadherin differ in their functional consequences. J Mol Biol $2001 ; 314$ (3): 445-454.

36. Vecsey-Semjen B, Becker KF, Sinski A, Blennow E, Vietor I, Zatlouka $\mathrm{K}$, Beug $\mathrm{H}$, Wagner $\mathrm{E}$ and Huber LA. Novel colon cancer cell lines leading to better understanding of the diversity of respective primary cancers. Oncogene 2002; 21 (30): 4646-4662.

37. Suriano G, Mulholland D, de Wever $O$, Ferreira P, Mateus AR, Bruyneel E, Nelson CC, Mareel MM, Yokota J, Huntsman D and Seruca R. The intracellular E-cadherin germline mutation V832 $M$ lacks the ability to mediate cell-cell adhesion and to suppress invasion. Oncogene 2003; 22 (36): 5716-9.
38. Suriano G, Oliveira MJ, Huntsman D, Mateus AR, Ferreira P, Casares F, Oliveira C, Carneiro F, Machado JC, Mareel M and Seruca R. E-cadherin germline missense mutations and cell phenotype: evidence for the independence of cell invasion on the motile capabilities of the cells. Hum Mol Genet 2003; 12 (22): 3007-3016.

39. Shin Y, Kim IJ, Kang HC, Park JH, Park HR, Park HW, Park MA, Lee JS, Yoon KA, Ku JL and Park JG. The E-cadherin -347G-> GA promoter polymorphism and its effect on transcriptional regulation. Carcinogenesis 2004; 25 (6): 895-899.

40. Li LC, Chui RM, Sasaki M, Nakajima K, Perinchery G, Au HC, Nojima D, Carroll P and Dahiya R. A single nucleotide polymorphism in the E-cadherin gene promoter alters transcriptional activities. Cancer Res 2000; 60 (4): 873-876.

41. Wu MS, Huang SP, Chang YT, Lin MT, Shun CT, Chang MC, Wang HP, Chen CJ and Lin JT. Association of the -160 C -> a promoter polymorphism of $\mathrm{E}$-cadherin gene with gastric carcinoma risk. Cancer 2002; 94 (5): 1443-8.

42. Humar B, Graziano F, Cascinu S, Catalano V, Ruzzo AM, Magnani M, Toro T, Burchill T, Futschik ME, Merriman T and Guilford P. Association of $\mathrm{CDH} 1$ haplotypes with susceptibility to sporadic diffuse gastric cancer. Oncogene 2002; 21 (53): 8192-8195.

43. Pharoah PD, Oliveira C, Machado JC, Keller G, Vogelsang H, Laux H, Becker KF, Hahn H, Paproski SM, Brown LA, Caldas C and Huntsman D. CDH1 c-160a promotor polymorphism is not associated with risk of stomach cancer. Int J Cancer 2002; 101 (2): 196-197.

44. Keller G, Vogelsang H, Becker I, Hutter J, Ott K, Candidus S, Grundei T, Becker KF, Mueller J, Siewert JR and Hofler H. Diffuse type gastric and lobular breast carcinoma in a familial gastric cancer patient with an E-cadherin germline mutation. Am J Pathol 1999; 155 (2): 337-342.

45. Pharoah PD, Guilford P and Caldas C. Incidence of gastric cancer and breast cancer in $\mathrm{CDHl}$ (E-cadherin) mutation carriers from hereditary diffuse gastric cancer families. Gastroenterology 2001; 121 (6): 1348-1353.

46. Aarnio M, Salovaara R, Aaltonen LA, Mecklin JP and Jarvinen HJ. Features of gastric cancer in hereditary non-polyposis colorectal cancer syndrome. Int J Cancer 1997; 74 (5): 551-555.

47. Peltomaki $P$. Role of DNA mismatch repair defects in the pathogenesis of human cancer. J Clin Oncol 2003; 21 (6): $1174-1179$

48. Suraweera N, Duval A, Reperant M, Vaury C, Furlan D, Leroy K, Seruca R, lacopetta B and Hamelin R. Evaluation of tumor microsatellite instability using five quasimonomorphic mononucleotide repeats and pentaplex PCR. Gastroenterology 2002; 123 (6): 1804-1811.

49. Varley JM, McGown G, Thorncroft M, Santibanez-Koref MF, Kelsey AM, Tricker KJ, Evans DG and Birch JM. Germ-line mutations of TP53 in Li-Fraumeni families: an extended study of 39 families. Cancer Res 1997; 57 (15): 3245-3252.

50. Jakubowska A, Nej K, Huzarski T, Scott RJ and Lubinski J. BRCA2 gene mutations in families with aggregations of breast and stomach cancers. Br J Cancer 2002; 87 (8): 888-891.

51. Jakubowska A, Scott R, Menkiszak J, Gronwald J, Byrski T, Huzarski T, Gorski B, Cybulski C, Debniak T, Kowalska E, Starzynska T, Lawniczak M, Narod S and Lubinski J. A high frequency of BRCA2 gene mutations in Polish families with ovarian and stomach cancer. Eur J Hum Genet 2003; 11 (12): 955-958.

52. Li QL, Ito K, Sakakura C, Fukamachi H, Inoue K, Chi XZ, Lee KY, Nomura S, Lee CW, Han SB, Kim HM, Kim WJ, Yamamoto H, Yamashita N, Yano T, Ikeda T, Itohara S, Inazawa J, Abe T, Hagiwara A, Yamagishi H, Ooe A, Kaneda A, Sugimura T, Ushijima 
T, Bae SC and lto Y. Causal relationship between the loss of RUNX3 expression and gastric cancer. Cell 2002; 109 (1): 113-124.

53. Shibata DM, Sato F, Mori Y, Perry K, Yin J, Wang s, Xu Y, Olaru A, Selaru F, Spring K, Youing J, Abraham JM and Meltzer SJ. Hypermethylation of HPPl is associated with hMLHl hypermethylation in gastric adenocarcinomas. Cancer Res 2002; 62 (20): 5637-5640.

54. Park WS, Lee JH, Shin MS, Park JY, Kim HS, Lee JH, Kim YS, Lee $\mathrm{SN}$, Xiao W, Park CH, Lee SH, Yoo NJ and Lee JY. Inactivating mutations of the caspase-10 gene in gastric cancer. Oncogene 2002; 21 (18): 2919-2925.

55. Takaku K, Miyoshi H, Matsunaga A, Oshima M, Sasaki N and Taketo MM. Gastric and duodenal polyps in Smad4 (Dpc4) knockout mice. Cancer Res 1999; 59 (24): 6113-6117.

56. Houlston R, Houlston R, Bevan S, Williams A, Young J, Dunlop M, Rozen P, Eng C, Markie D, Woodford-Richens K, Rodriguez-Bigas MA, Leggett B, Neale K, Phillips R, Sheridan E, Hodgson S, Iwama T, Eccles D, Bodmer W and Tomlinson I. Mutations in DPC4 (SMAD4) cause juvenile polyposis syndrome, but only account for a minority of cases. Hum Mol Genet 1998; 7 (12): 1907-1912.

57. Howe JR, Roth S, Ringold JC, Summers RW, Jarvinen HJ, Sistonen P, Tomlinson IP, Houlston RS, Bevan S, Mitros FA, Stone EM and Aaltonen LA. Mutations in the SMAD4/DPC4 gene in juvenile polyposis. Science 1998; 280 (5366): 1086-1088.

58. Lynch HT, Grady W, Lynch JF, Tsuchiya KD, Wiesner G and Markowitz SD. E-cadherin mutation-based genetic counseling and hereditary diffuse gastric carcinoma. Cancer Genet Cytogenet 2000; 122 (1): 1-6.

59. Blaser MJ. The changing relationships of Helicobacter pylori and humans: implications for health and disease. J Infect Dis 1999; 179 (6): 1523-1530.

60. Everhart JE. Recent developments in the epidemiology of Helicobacter pylori. Gastroenterol Clin N Am 2000; 29 (3): 559-578.

61. Drumm B, Perez-Perez GI, Blaser MJ and Sherman PM Intrafamilial clustering of Helicobacter pylori infection. N Engl J Med 1990; 322 (6): 359-363.

62. Parsonnet J, Friedman GD, Vandersteen DP, Chang Y, Vogelman $\mathrm{JH}$, Orentreich $\mathrm{N}$ and Sibley RK. Helicobacter pylori infection and the risk of gastric carcinoma. N Engl J Med 1991; 325 (16): 1127-1131.

63. Huang J-Q, Sridhar S, Chen Y and Hunt RH. Meta-analysis of the relationship between Helicobacter pylori seropositivity and gastric cancer. Gastroenterology 1998; 114 (6): 1169-1179.

64. Ekstrom AM, Serafini M, Nyren O, Hansson LE, Ye W and Wolk A. Dietary antioxidant intake and the risk of cardia cancer and noncardia cancer of the intestinal and diffuse types: a population-based case-control study in Sweden. Int J Cancer 2000; 87 (1): 133-140.

65. Uemura N, Okamoto S, Yamamoto S, Matsumura N, Yamaguch S, Yamakido M, Taniyama K, Sasaki N and Schlemper RJ. Helicobacter pylori infection and the development of gastric cancer. N Engl J Med 2001; 345 (1 1): 784-789.

66. Cover TL, Krishna US, Israel DA and Peek RM Jr. Induction of gastric epithelial cell apoptosis by Helicobacter pylori vacuolating cytotoxin. Cancer Res 2003; 63 (5): 951-957.

67. Smoot DT, Elliott TB, Verspaget HW, Jones D, Allen CR, Vernon KG, Bremner T, Kidd LC, Kim KS, Groupman JD and Ashktorab $\mathrm{H}$. Influence of Helicobacter pylori on reactive oxygen-induced gastric epithelial cell injury. Carcinogenesis 2000; 21 (11): 2091-2095.

68. Figueiredo C, van Doorn LJ, Nogueira C, Soares JM, Pinho C, Figueira P, Quint WGV and Carneiro F. Helicobacter pylori genotypes are associated with clinical outcome in Portuguese patients and show a high prevalence of infections with multiple strains. Scand J Gastroenterol 2001; 36 (2): 128-135.

69. Figueiredo C, Machado JC, Pharoah P, Seruca R, Sousa S, Carvalho R, Capelinha AF, Quint W, Caldas C, van Doorn LJ, Carneiro F and Sobrinho-Simoes M. Helicobacter pylori and interleukin-1 genotyping: an opportunity to identify high-risk individuals for gastric carcinoma. J Natl Cancer Inst 2002; 94 (22): 1680-1687.

70. Peek RM and Blaser MJ. Helicobacter pylori and gastrointestinal tract adenocarcinomas. Nat Rev Cancer 2002; 2 (1): 28-37.

71. Carneiro F, Taveira-Gomes A, Cabral-Correia A, VasconcelosTeixeira A, Barreira R, Cardoso-Oliveira M and Sobrinho-Simoes M. Characteristics of the gastric mucosa of direct relatives of patients with sporadic gastric carcinoma. Eur J Cancer Prev 1993; 2 (3): 239-46.

72. Brenner $\mathrm{H}$, Bode $\mathrm{G}$ and Boeing $\mathrm{H}$. Helicobacter pylori infection among offspring of patients with stomach cancer. Gastroenterology 2000; 118 (1): 31-35.

73. Brenner $\mathrm{H}$, Arndt $\mathrm{V}$, Sturmer T, Stegmaier $\mathrm{C}$, Ziegler $\mathrm{H}$ and Dhom G. Individual and joint contribution of family history and Helicobacter pylori infection to the risk of gastric carcinoma. Cancer 2000; 88 (2): 274-279.

74. El-Omar EM, Oien K, Murray LS, El-Nujumi A, Wirz A, Gillen D, Williams C, Fullarton $G$ and McColl KEL. Increased prevalence of precancerous changes in relatives of gastric cancer patients: critical role of Helicobacter pylori. Gastroenterology 2000; 118 (1): 22-30.

75. Malfertheiner P, Megraud F, O'Morain C, Hungin AP, Jones R, Axon A, Graham DY, Tytgat $G$ and the European Helicobacter Pylori Study Group (EHPSG). Current concepts in the management of Helicobacter pylori infection-the Maastricht 2-2000 Consensus Report. Aliment Pharmacol Ther 2002; 16 (2): 167-180.

76. Correa P. Human gastric carcinogenesis: a multistep and multifactorial process - First American Cancer Society Award Lecture on Cancer Epidemiology and Prevention. Cancer Res 1992; 52 (24): 6735-6740.

77. Kuipers EJ, Uyterlinde AM, Pena AS, Roosendaal R, Pals G, Nelis GF, Festen HP and Meuwissen SG. Long-term sequelae of Helicobacter pylori gastritis. Lancet 1995; 345 (8964): 1525 1528.

78. Santtila S, Savinainen K and Hurme M. Presence of the IL-1 RA allele $2\left(\mathrm{IL} 1 \mathrm{RN}^{*} 2\right)$ is associated with enhanced IL-1beta production in vitro. Scand J Immunol 1998; 47 (3): 195-198.

79. Pociot F, Molvig J, Wogensen L, Worsaae H and Nerup J. A Taql polymorphism in the human interleukin-1 beta (IL-1 beta) gene correlates with IL-1 beta secretion in vitro. Eur J Clin Invest 1992; 22 (6): 396-402.

80. Wilson AG, Symons JA, McDowell TL, McDevitt HO and Duff GW. Effects of a polymorphism in the human tumor necrosis factor alpha promoter on transcriptional activation. Proc $\mathrm{Natl}$ Acad Sci USA 1997; 94 (7): 3195-3199

81. El-Omar EM, Carrington M, Chow WH, McColl KE, Bream JH, Young HA, Herrera J, Lissowska J, Yuan CC, Rothman N, Lanyon G, Martin M, Fraumeni JFJ and Rabkin CS. Interleukin-1 polymorphisms associated with increased risk of gastric cancer (published erratum appears in Nature 2001; 412: 99). Nature 2000; 404 (6842): 398-402.

82. Machado JC, Pharoah P, Sousa S, Carvalho R, Oliveira C, Figueiredo C, Amorim A, Seruca R, Caldas C, Carneiro F and Sobrinho-Simoes M. Interleukin 1B and interleukin IRN polymorphisms are associated with increased risk of gastric carcinoma. Gastroenterology 2001; 121 (4): 823-829.

83. Machado JC, Figueiredo C, Canedo P, Pharoah P, Carvalho R, Nabais S, Alves CC, Campos ML, van Doorn L, Caldas C, Seruca 
R, Carneiro F and Sobrinho-Simoes M. A pro-inflammatory genetic profile increases the risk of chronic atrophic gastritis and gastric carcinoma. Gastroenterology 2003; 125 (2): 364-371.

84. El Omar EM, Rabkin CS, Gammon MD, Vaughan TL, Risch HA, Schoenberg JB, Stanford JL, Mayne ST, Goedert J, Blot WJ, Fraumeni JF, Jr. and Chow WH. Increased risk of noncardia gastric cancer associated with proinflammatory cytokine gene polymorphisms. Gastroenterology 2003; 124 (5): 1193-1201.

85. Yoon KA, Ku JL, Yang HK, Kim WH, Park SY and Park JG Germline mutations of E-cadherin gene in Korean familial gastric cancer patients. J Hum Genet 1999; 44 (3): 177-180.

86. lida S, Akiyama Y, Ichikawa W, Yamashita T, Nomizu T, Nihei Z, Sugihara $K$ and Yuasa Y. Infrequent germ-line mutation of the E-cadherin gene in Japanese familial gastric cancer kindreds. Clin Cancer Res 1999; 5 (6): 1445-1447.

87. Avizienyte E, Launonen V, Salovaara R, Kiviluoto T and Aaltonen L. E-cadherin is not frequently mutated in hereditary gastric cancer. J Med Genet 2001; 38 (1): 49-52.

88. Dussaulx-Garin L, Blayau M, Pagenault M, Le Berre-Heresbach N, Raoul JL, Campion JP, David V and Bretagne JF. A new mutation of $\mathrm{E}$-cadherin gene in familial gastric linitis plastica cancer with extra-digestive dissemination. Eur J Gastroenterol Hepatol 2001; 13 (6): 711-715.

89. Humar B, Toro T, Graziano F Muller H, Dobbie Z, Kwang-Yang H, Eng C, Hampel H, Gilbert D, Winship I, Parry S, Ward R, Findlay M, Christian A, Tucker M, Tucker K, Merriman T and Guilford P. Novel germline $\mathrm{CDH} 1$ mutations in hereditary diffuse gastric cancer families. Hum Mutat 2002; 19 (5): 518-525. 